8. Padhi, R. K., Subramanian, S. and Satpathy, K. K., Formation, distribution, and speciation of DBPs (THMs, HAAs, $\mathrm{ClO}_{2-}$ and $\mathrm{ClO}_{3}-$ ) during treatment of different source water with chlorine and chlorine dioxide. Chemosphere, 2019, 218, 540-550.

9. Gordon, G., Slootmaekers, B., Tachiyashiki, S. and Delmer, W. W. I., Minimizing chlorite ion and chlorate ion in water treated with chlorine dioxide. J. Am. Water Works Assoc., 1990, 82, 160-165.

10. Westerhoff, P., Chao, P. and Mash, H., Reactivity of natural organic matter with aqueous chlorine and bromine. Water Res. 2004, 38, 1502-1513.

11. Zhang, H., Qu, J., Liu, H. and Wei, D., Characterization of dissolved organic matter fractions and its relationship with the disinfection by-product formation. J. Environ. Sci., 2009, 21, 54-61.

12. Padhi, R. K., Subramanian, S., Mohanty, A. K. and Satpathy, K. K., Comparative assessment of chlorine reactivity and trihalomethanes formation potential of three different water sources. J. Water Process Eng., 2019, 29, 100769.

13. Padhi, R. K., Sowmya, M., Mohanty, A. K., Bramha, S. N. and Satpathy, K. K., Formation and speciation characteristics of brominated trihalomethanes in seawater chlorination. Water Environ. Res., 2012, 84, 2003-2009.

14. Rajamohan, R., Vinnitha, E., Venugopalan, V. P. and Narasimhan, S. V., Chlorination by-products and their discharge from the cooling water system of a coastal electric plant. Curr. Sci., 2007, 93, 1608-1612.

15. Golea, D. M., Upton, A., Jarvis, P., Moore, G., Sutherland, S., Parson, S. A. and Judd, S. J., THM and HAA formation from NOM in raw and treated surface waters. Water Res., 2017, 112, 226-235.

16. Yang, X., Shang, C. and Westerhoff, P., Factors affecting formation of haloacetonitriles, haloketones, chloropicrin and cyanogen halides during chloramination. Water Res., 2007, 41, 1193-1200.

17. Zhang, H., Dong, H., Adams, C., Qiang, Z., Luan, G. and Wang, L., Formation and speciation of disinfection byproducts during chlor(am)ination of aquarium seawater. J. Environ. Sci., 2015, 33, $116-124$.

18. Hong, H., Xiong, Y., Ruan, M., Liao, F., Lin, H. and Liang, Y., Factors affecting THMs, HAAs and HNMs formation of Jin Lan Reservoir water exposed to chlorine and monochloramine. Sci. Total Environ., 2013, 444, 196-204.

19. Regli, S. et al., Estimating potential increased bladder cancer risk due to increased bromide concentrations in sources of disinfected drinking waters. Environ. Sci. Technol., 2015, 49, 13094-13102.

20. Yu, H.-W., Oh, S.-G., Kim, I. S., Pepper, I., Snyder, S. and Jang, A., Formation and speciation of haloacetic acids in seawater desalination using chlorine dioxide as disinfectant. J. Ind. Eng. Chem., 2015, 26, 193-201.

21. Al-Otoum, F., Al-Ghouti, M. A., Ahmed, T. A., Abu-Dieyeh, M and Ali, M., Disinfection by-products of chlorine dioxide (chlorite, chlorate, and trihalomethanes): Occurrence in drinking water in Qatar. Chemosphere, 2016, 164, 649-656.

22. Pereira, J. T. et al., Comparing the efficacy of chlorine, chlorine dioxide, and ozone in the inactivation of Cryptosporidium parvum in water from Parana State, Southern Brazil. Appl. Biochem. Biotechnol., 2008, 151, 464-473.

ACKNOWLEDGMENT. We thank the Director, SQRMG, IGCAR, and Director, IGCAR, Kalpakkam for their constant encouragement and support in the pursuit of environmental research.

Received 17 May 2018; revised accepted 16 July 2019

\section{Quantitative assessment of crop species diversity in shifting cultivation system of Eastern Himalaya}

\author{
D. K. Pandey ${ }^{1 * *}$, P. Adhiguru ${ }^{2}$, S. Vimla Devi ${ }^{3}$, \\ Shivani Dobhal ${ }^{1}$, S. K. Dubey ${ }^{4}$ and T. S. Mehra ${ }^{1}$ \\ ${ }^{1}$ College of Horticulture and Forestry, \\ Central Agricultural University (I), Pasighat 791 102, India \\ ${ }^{2}$ Division of Agricultural Extension, KAB-I, Indian Council of \\ Agricultural Research, New Delhi 110 012, India \\ ${ }^{3}$ ICAR-National Bureau of Plant Genetic Resources, \\ New Delhi 110 012, India \\ ${ }^{5}$ ICAR-Agricultural Technology Application Research Institute, \\ Kanpur 278 002, India
}

The narrowing of diversity in crop species contributing to the world's food supplies has been considered a potential threat to food security. The present study quantifies crop species diversity in controversial shifting cultivation system (SCS) using primary data from 52 villages spread across six North-Eastern (NE) hill states of India. The findings reveal that SCS is much diversified compared to settled cultivation system. Along with cereals, millets and pulses, the upland tribes grow a variety of horticultural crops on SC land. At the aggregate level, horticultural crops in the sampled states were observed to be much diversified and the mean diversification index value was found to be 0.79 (Simpson's Diversity Index) for the six NE hill states on SC land. The present study documented 25 cultivars of vegetables, 22 cultivars of fruits, spices and plantation crops, and 12 field crops in SCS, besides many minor fruits and underutilized vegetables. However, the most densely populated crop species were rice, maize and finger millet in the case field crops. Vegetable crops included pumpkin, potato and ash gourd, and fruit crops included banana, pineapple and citrus, while spices like ginger, chilli and turmeric were densely cultivated on SC land. Thus, the prevailing crop species in SCS had their own attributes, performances and challenges. Experiences of the present study shall be the guiding benchmark for those who negate the possibilities of agrobiodiversity in SCS.

Keywords: Agrobiodiversity, crop diversity, upland tribes, shifting cultivation.

FOOD security of any country is primarily dependent upon the extent to which different food groups are produced and consumed, which underlines the importance of crop diversity. Crop diversity can be described as plant genetic resources for food and agriculture (PGRFA), and implies the nature of diversity within and among crops, their wild relatives and wild edible plant species. Crop diversity has evolved over thousands of years of interaction

*For correspondence. (e-mail: dkpextension@gmail.com) 
between nature and humans in agricultural activities. The level of crop diversity forms the biological foundation for food production and food security, and further contributing to economic development ${ }^{1}$. One of the crucial issues in achieving local and global food security is managing and conserving agricultural crop diversity, especially in the context of changing environmental scenarios like rising temperatures, changing seasonal patterns and frequent occurrence of extreme weather conditions. There is growing concern globally that agricultural productivity would get affected due to climate change. By 2050, to feed the estimated global population of nine billion people $^{2}$, transforming the agricultural sector would be crucial. One of the key reasons attributed to loss of biodiversity is climate change. However, crop diversity if adequately maintained would contribute significantly towards mitigating the adverse effects of climate change and also support adapting to climate change. According to a report by Food and Agricultural Organization (FAO), among the adaptation solutions for climate change, the effective use of crop diversity emerges as one of the key options. In this context, broadening the genetic base of crops is considered vital for such adaptation. Therefore, sustained availability and access to both traditional and improved varieties would greatly help in augmenting crop productivity in the future.

Farmers maintain considerable crop diversity while practicing traditional agricultural production systems and such an approach helps them in the form of 'sustainable insurance' to meet their food and income needs and preferences while experiencing varying socio-economic conditions. On-farm management of crop diversity depending upon the varying needs leads to continued evolution of diversity fitting into changing production and consumption scenarios, and such experience would be significantly useful in current crop improvement programmes while providing options for future increase in crop productivity. Thus, the evolutionary experience in diversity would help famers and plant breeders in developing new plant varieties ${ }^{3}$. Apart from developing improvized crops, the inherent traditional knowledge associated with conserving crop diversity in terms of how to grow and maintain them is of importance. Therefore, giving due consideration to values held at the family and community levels as well as giving weightage to existing social and cultural systems and structures is essential while making changes at the production level ${ }^{4}$.

Shifting cultivation system (SCS) is one of the traditional systems of agriculture in which, farmers cultivate a variety of crops in a given piece of land for a period of 1-3 years and then move to another segment of land. SC also called jhum cultivation is the prime mode of agricultural production and also a means of economic sustenance of rural households in the hilly regions of Arunachal Pradesh, Assam, Manipur, Meghalaya, Mizoram, Nagaland and Tripura. In mixed cropping, a combination of crops like rice, maize, millets, cotton and other soil health-enriching crops like legumes are cultivated. The harvesting time of these crops varies and therefore farmers can harvest the crops at different times and thus have a variety of foods throughout the year. Local cultivars of cereals and vegetables are mostly grown by the farmers. In the recent past, usefulness of these kinds of local crop varieties and contribution of farmers and other agencies in conserving such varieties have been well recognized. However, cultivation of such local varieties in a sustained manner is getting affected due to inappropriate enabling environment. One of the reasons for lack of sustaining local varieties is substantial promotion and subsequent widespread adoption of high-yielding varieties due to multiple factors, including better marketability. As a result, several local varieties have been discontinued for cultivation, and the associated knowledge related to their cultivation and the benefits of such varieties are also getting lost. In the eastern Himalaya, ethnic minorities and marginalized upland communities predominantly practice $\mathrm{SC}$.

In fact, SC has become an integral part of life in the region ${ }^{6}$. This is evident from the fact that the Eastern Himalaya is one of the 34 biodiversity hotspots identified in the world. India is one of the 8 centres of origin of cultivated plants and one of the 12 mega gene centres of the world ${ }^{7}$. The recognition of biodiversity hotspots is gaining importance globally, because awareness on conservation of biodiversity is increasing. However, recognition and rewarding of positive aspects of $\mathrm{SC}$ is still lacking. Since, the key practices of SC like cutting, slashing and burning of trees are more tangible, these cultivators are easily being blamed; rather what is needed is focus and holistic understanding on the process, factors and other players involved in SC. According to Darlong ${ }^{8}$, '... the historical value of shifting cultivation is often seen in the context of the in situ conservation of so many varieties of edible food crops through the practice of shifting cultivation.... It is often argued that had there been no shifting cultivation, perhaps many of these germplasms would have been lost in the wild or would not have been possible to conserve as they are today.' Thus, it is to be understood that conservation and maintenance of germplasm has drawn support traditionally from SC by virtue of its diversified cultivation of local varieties.

For effective monitoring of the depletion of genetic resources, i.e. genetic erosion, agrobiodiversity inventories serve as fundamental reference points. Baseline information is a prerequisite to understanding the nature of existence of local crop diversity. There is also a need to understand the associated social, economic, geographic and environmental situations. For this, agrobiodiversity information inventories are crucial and this kind of information is useful for building strategies to sustain the cultivation of local varieties, collect and conserve material 
ex situ, and also for monitoring the extent of change in biodiversity. Farmers and other maintainers can play a greater role in creating and maintaining inventories, because they are the creators, innovators and custodians of crop diversity. Therefore, there is a need to honour their rights in terms of protection of knowledge, also in sharing the benefits arising from the use of plant genetic material, and also their contribution in the decisionmaking process. The requirement for conducting survey and preparation of inventory of PGRFA is emphasized in Article 5 and protecting the rights of farmers in Article 9 of the International Treaty on PGRFA popularly known as the International Seed Treaty. Furthermore, in many North Eastern Himalayan (NEH) states, there is a dearth of documentation of diversity, owing to low priority, inaccessibility and remoteness of the region ${ }^{9}$. In view of this and the importance on local crop diversity, the present study was undertaken to gather baseline information needed to understand crop diversity that exists in SCS of NER.

The present study was conducted during 2016-17 in the six Indian states of NEH, namely Arunachal Pradesh, Manipur, Meghalaya, Mizoram, Nagaland and Tripura. From each state, one district having the highest density of tribal families practicing SC was selected for the study. From Upper Subansiri (Arunachal Pradesh), Churachandpur (Manipur), West Garo hills (Meghalaya) and Mon (Nagaland), a sample of 100 respondents practising SC were randomly sampled. From Siaha (Mizoram) and Dhalai (Tripura), a sample of 50 respondents practising SC were selected randomly for the study. Thus, the total sample drawn for the present study was 500 .

Species diversity comprising two basic constituents, i.e. richness and evenness represents the various kinds of species within a community. Species richness indicates the number of species present, whereas evenness implies how existing species dominate in a community or whether these species are represented by approximately equal numbers ${ }^{10}$. The most widely used indices for estimation of $\alpha$-diversity are the Margalef, Shannon-Weiner and Simpson indices. Simpson diversity index (SDI) ${ }^{11}$ is used for assessing crop species diversity ${ }^{11}$. The index is suitable for measuring community diversity in various locations, diversity difference in population, etc. Because the instrument is simple and easy to use, its acceptability is very high ${ }^{12}$. Crop diversity is calculated using the following formula of SDI

$$
D=1-\frac{\sum n(n-1)}{N(N-1)},
$$

where $n$ is the number of individuals of each species and $N$ is the total number of individuals of all species.

Abundance and density refer to the number of species in a given vegetation structure/sample plot. Both are quantitative derivatives of the number of species in a studied community structure of plant species. Abundance of any individual plant species is expressed as a percentage of the total number of species present in community/sample plots, and therefore it is a relative measure. In sampling the abundance of species, it is a measure of the number of individual species occurrence in the studied community structure/sample plot. Taken together, abundance and density are of great importance in determining the community structure.

$$
\begin{aligned}
& \text { Abundance }=\frac{\left(\begin{array}{c}
\text { Total no. of individuals } \\
\text { of the species }
\end{array}\right)}{\left(\begin{array}{c}
\text { No. of quadrates per } \\
\text { unit in which they occur }
\end{array}\right)} \times 100 . \\
& \text { Density }=\frac{\left(\begin{array}{c}
\text { Total no. of individuals } \\
\text { of the species }
\end{array}\right)}{(\text { No. of quadrates per unit studied })} \times 100 .
\end{aligned}
$$

Crop diversification index was worked out using tribal household-level information (Figure 1). At the aggregate level, cereal and pulse crops in the sampled states seem to be moderately diversified. The diversification index was found to be 0.61 for the NE hill region as a whole on SC land. It varied from 0.53 for Dhalai, Tripura to 0.76 for Upper Subansiri, Arunachal Pradesh. The agriculture diversification index value indicates that SC cultivation is the most diversified in Arunachal Pradesh and least diversified in Tripura. The reason for a lower diversification index in Tripura is because the cropping pattern in this state is concentrated more on cereal crops, vegetables and spices. Diversity in horticultural crops, particularly vegetables, was found to be much diversified in SCS of all the sampled states. The diversification index was found to be 0.86 for the NE hill region as a whole on SC land.

Figure 2 reveals crop species distribution in SCS in the sample area documented during the study. Maximum (39)

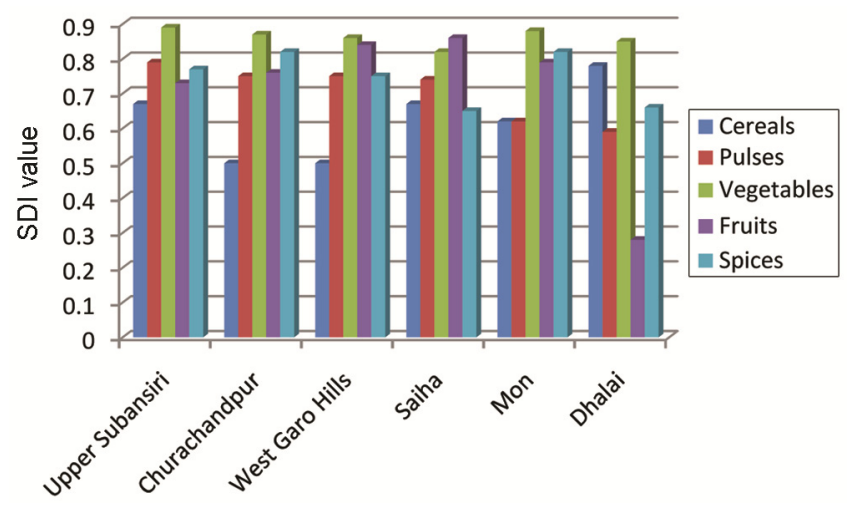

Figure 1. Crop diversification index. 


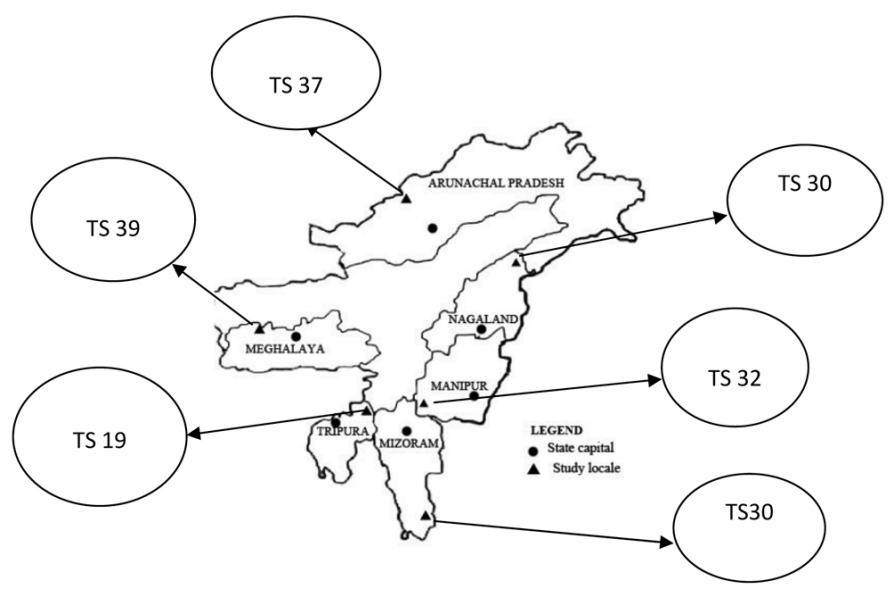

Figure 2. Distribution of crop species in the sample area (TS, Total species).

Table 1. Density and abundance of the recorded field crops and vegetable species

\begin{tabular}{|c|c|c|}
\hline Crops & Density & Abundance \\
\hline \multicolumn{3}{|l|}{ Field crops } \\
\hline Rice (Oryza sativa L.) & 90.50 & 90.50 \\
\hline Maize (Zea mays L.) & 80.00 & 80.00 \\
\hline Finger millet (Eleusine coracana) & 29.00 & 58.00 \\
\hline Sorghum (Sorghum bicolor) & 1.33 & 8.00 \\
\hline Cotton (Gossypium hirsutum) & 8.00 & 48.00 \\
\hline Sesame (Sesamum indicum L.) & 14.33 & 86.00 \\
\hline Jute (Corchorus olitorius) & 5.33 & 32.00 \\
\hline Pigeon pea (Cajanus cajan) & 20.17 & 30.25 \\
\hline Cowpea (Vigna sinesis L.) & 11.83 & 14.20 \\
\hline Chickpea (Cicer arietinum) & 7.67 & 11.50 \\
\hline Soybean (Glycine max) & 3.17 & 9.50 \\
\hline Blackgram (Vigna mungo) & 3.00 & 4.50 \\
\hline \multicolumn{3}{|l|}{ Vegetable crops } \\
\hline Cauliflower (Brassica oleracea var. botrytis) & 21.17 & 31.75 \\
\hline Cabbage (Brassica oleracea var. capitata) & 26.00 & 39.00 \\
\hline Pumpkin (Cucurbita pepo) & 60.67 & 60.67 \\
\hline Chow chow (Sechium edule) & 23.00 & 27.60 \\
\hline Drumstick (Moringa oleifera) & 5.67 & 34.00 \\
\hline Potato (Solanum tuberosum) & 46.50 & 46.50 \\
\hline Ash gourd (Benincasa hispida) & 29.17 & 29.17 \\
\hline Carrot (Daucas carota) & 1.50 & 4.50 \\
\hline Okra (Abelmoschus esculentus) & 2.83 & 8.50 \\
\hline Bitter gourd (Momordica charantia) & 2.33 & 7.00 \\
\hline Bottle gourd (Lagenaria siceraria) & 4.67 & 9.33 \\
\hline Brinjal (Solanum melongena) & 15.17 & 18.20 \\
\hline Yam (Dioscorea spp.) & 13.83 & 20.75 \\
\hline Collocasia (Colocasia esculenta) & 25.33 & 38.00 \\
\hline $\begin{array}{l}\text { Elephant foot yam } \\
\quad \text { (Amorphophallus paeoniifolius) }\end{array}$ & 4.67 & 28.00 \\
\hline Mesta (Hibiscus cannabinus) & 12.33 & 74.00 \\
\hline Rapeseed (Brassica napus) & 0.67 & 4.00 \\
\hline Mustard (Brassica spp.) & 19.17 & 23.00 \\
\hline Tapioca (Manihot esculenta) & 3.17 & 9.50 \\
\hline Tomato (Solanum lycopersicum) & 10.33 & 15.50 \\
\hline Cucumber (Cucumis sativas) & 20.00 & 24.00 \\
\hline Radish (Raphanus sativus) & 0.67 & 4.00 \\
\hline Long bean (Vigna unguiculata) & 1.33 & 8.00 \\
\hline Watermelon (Citrullus lanatus) & 2.17 & 13.00 \\
\hline Muskmelon (Cucumis melo) & 2.17 & 13.00 \\
\hline
\end{tabular}

crop species richness was found in West Garo Hills district of Meghalaya, followed by Upper Subansiri district of Arunachal Pradesh. Lowest crop species richness was found in Dhalai district of Tripura, whereas similar number of crop species was documented form Mon in Nagaland, Churachandpur, in Manipur, and Saiha in Mizoram.

As mentioned earlier, species diversity is described by two basic constituents, i.e. richness and evenness. Figure 2 presents the species richness and Table 1 presents the evenness of the documented species.

Table 1 shows that rice is the principal crop grown by upland tribes in the sampled area. All the respondents of Upper Subansiri in Arunachal Pradesh, Mon in Nagaland and Dhalai in Tripura reported $100 \%$ rice (Oryza sativa) cultivation on SC land, whereas Churachandpur in Manipur, West Garo Hills in Meghalaya and Saiha in Mizoram reported $87 \%, 94 \%$ and $62 \%$ rice cultivation respectively. Also, $95 \%$ and $94 \%$ of the respondents in Upper Subansiri and West Garo Hills reported growing maize (Zea mays). The other districts in declining order are Churachandpur (74\%), Dhalai (72\%) and Saiha (50\%). Among millets, finger millet (Eleusine coracana) was cultivated in Upper Subansiri (86\%), Saiha (66\%) and Mon (22\%). Table 1 shows that sorghum (Sorghum bicolor) cultivation on SC land is prevalent among $8 \%$ respondents in Mon, Nagland, whereas the remaining states did not grow sorghum on SC land. Tripura was the only state that reported growing cotton, sesame and jute on SC land; these three crops were grown by $48 \%, 86 \%$ and $32 \%$ respondents respectively. Among pulse crops, pigeon pea (Cajanus cajan) was reported to be grown in Upper Subansiri and Mon, and $80 \%$ respondents of Dhalai were reported to grow pigeon pea on SC land.

In the studied area, 12 field crops, 25 vegetable crops and 22 crop species of fruit condiments and spices were found in SCS. The most densely populated species under field crops was rice (density 90.50) followed by maize 
(density 80.00). In vegetable crops, maximum density was in the case of pumpkin (60.67). Chilli (Capsicum annuum) was the next noticeable species with highest density of 63.33 in spices crop category. The abundant species for vegetable crops was mesta (74.00), whereas under field crops, the species with high density also had high abundance (Tables 1 and 2).

Our assessment shows high diversity of crop species in SCS from the sampled area (Figure 1). Maintenance of this biodiversity is essential for the sustainable production of food and other agricultural products, and the benefits these provide to humanity, including food security, nutrition and livelihood for the tribals of NE India. The most densely populated crop species were rice, maize and finger millet in the case field crops. Among vegetable crops pumpkin, potato and ash gourd and among fruit crops banana, pineapple and citrus, and spices like ginger, chilli and turmeric were also cultivated in SCS. The present study observed significant diversity within species (Figure 3) and much agricultural biodiversity is now conserved ex situ in gene banks or breeders' materials.

Only small-scale isolated studies on crop species diversity have been reported from such landscape at different time intervals, such as about 41 crops from Nagaland ${ }^{13}$, 72 crops in West Siang district ${ }^{14}$ and over 30 different varieties of vegetables in Upper Siang district of Arunachal Pradesh ${ }^{15}$. In the Chittagong hill tracts of Bangladesh, farmers cultivate more than 40 crop species on the $\mathrm{SC}$ landscape ${ }^{16}$. The documentation made in the present study on diversity of crops is in similarity with the sporadic studies conducted elsewhere in SCS. Such agrodiversity in SC is one of the key factors due to which farmers are attracted to SCS. However, spatial difference in crop species richness has been observed (Figure 2), and the main drivers behind it are variability in population density and fallow length. Figure 3 reveals the landrace diversity in different crops cultivated in SCS in NE India, which offers an opportunity for farmers and plant breeders to develop higher-yielding and more productive varieties that have improved quality characteristics required by farmers and desired by consumers. In the case of principal cereal crops like rice, it has been estimated that more than $70 \%$ of the total rice varieties grown in Arunachal Pradesh are traditional cultivars or landraces having low to very low productivity ${ }^{17}$. Despite having low yield potential, the hill rice landraces grown in the mountains under SCS possess many adaptive traits such as cold tolerance important for crop improvement programmes. The traditional rice landraces possess wide genetic variability valuable for breeding ${ }^{18,19}$. The frequency of use of local seeds is significantly higher among the shifting cultivators ${ }^{20}$. It was found that the traditional land races are important reservoirs of valuable traits which need special attention for future conservation ${ }^{21}$. These landraces and wild species are having immense potentials for effectively utilizing in breeding programmes for developing improved varieties of rice with quality.

The depletion of worldwide biodiversity is happening at an unprecedented rate in all the ecosystems, including agro-ecosystems during the past decades. A few main causes of loss of agricultural biodiversity include homogenization of agricultural production systems because of intensification of agricultural systems which are also associated with specialization by plant and animals breeders, and the harmonizing effects of globalization. More specifically, genetic erosion and genetic vulnerability of specialized crops and livestock at an increasing rate lead to accelerated biodiversity loss. Such types of challenges are also affecting SCS in multiple dimensions. Factors such as shrinkage of community land, expansion of road network and access to urban markets also affect biodiversity. Moreover, national policies have brought changes in land uses towards permanent farming like horticulture and tree farming and in turn leading to decreased SC landscape agrobiodiversity. In this context it is to be observed that in the region, land under SC is being brought under commercial plantations which include horticulture crops and rubber plantation ${ }^{22}$. Other than the cultivated piece of land in SCS, the patch of land which is left to recuperate by allowing regeneration of vegetation is also contributing for biodiversity. Thus, the length off allow period is the key factor for the degree to which biodiversity accumulates on individual patches in SC landscapes ${ }^{23}$.

The above findings on crop diversification among tribal households in the region clearly indicate that they cultivate a variety of crops. However, with the growing

Table 2. Density and abundance of recorded fruit, condiments and spices crops

\begin{tabular}{lrr}
\hline Crops & Density & Abundance \\
\hline Pineapple (Ananus sativus) & 30.50 & 36.60 \\
Banana (Musa spp.) & 44.17 & 44.17 \\
Jackfruit (Artocarpus integra) & 17.50 & 21.00 \\
Lemon (Citrus limonium) & 22.50 & 22.50 \\
Orange (Citrus aurantium) & 22.00 & 26.40 \\
Papaya (Carica papaya) & 0.83 & 5.00 \\
Strawberry (Fragaria ananassa) & 3.00 & 18.00 \\
Tamarind (Tamarindus indica) & 1.00 & 6.00 \\
Grape (Vitis vinifera) & 1.33 & 8.00 \\
Passion fruit (Passiflora edulis) & 2.50 & 15.00 \\
Litchi (Litchi chinensis) & 1.67 & 10.00 \\
Mango (Mangifera indica) & 1.17 & 7.00 \\
Ginger (Zingiber officinale) & 62.83 & 62.83 \\
Chili (Capsicum annuum) & 63.33 & 63.33 \\
Onion (Allium cepa) & 15.33 & 23.00 \\
Garlic (Allium sativum) & 10.67 & 16.00 \\
Turmeric (Curcuma longa) & 36.17 & 36.17 \\
Local coriander (Eryngium foetidum) & 17.83 & 17.83 \\
Cashew nut (Anacardium occidentale) & 2.83 & 17.00 \\
Beetle nut (Areca catechu) & 9.00 & 54.00 \\
Coconut (Cocos nucifera) & 1.00 & 6.00 \\
Tea (Camellia sinensis) & 0.50 & 3.00 \\
\hline
\end{tabular}



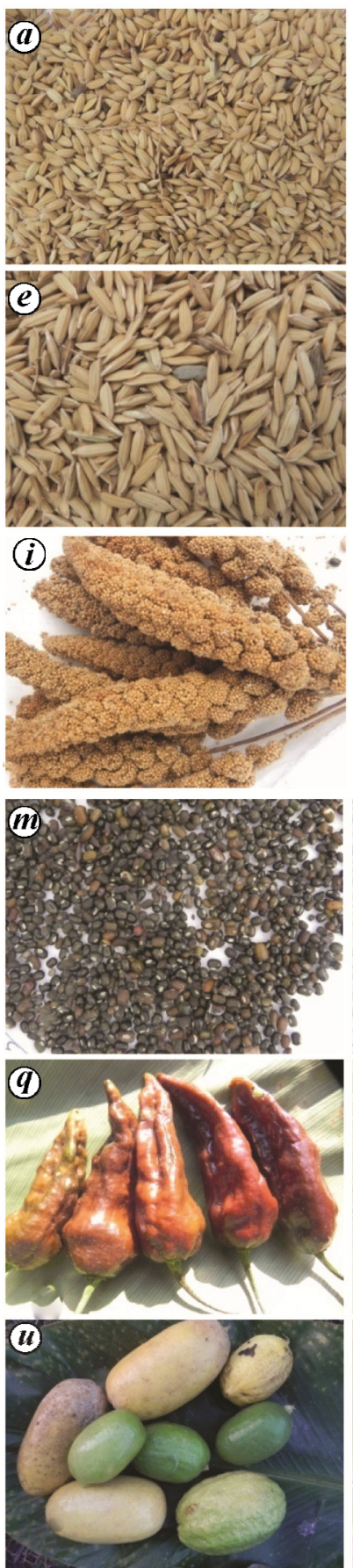
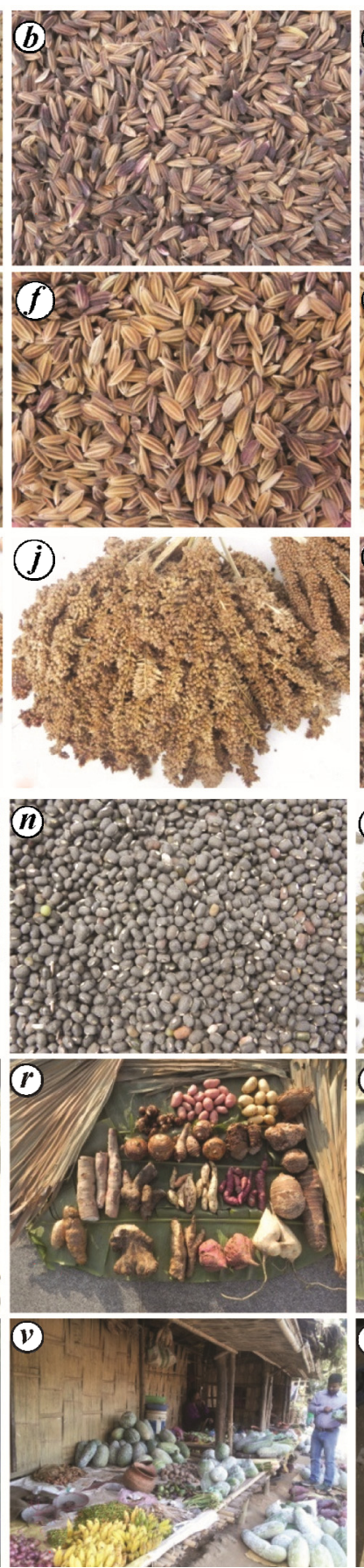
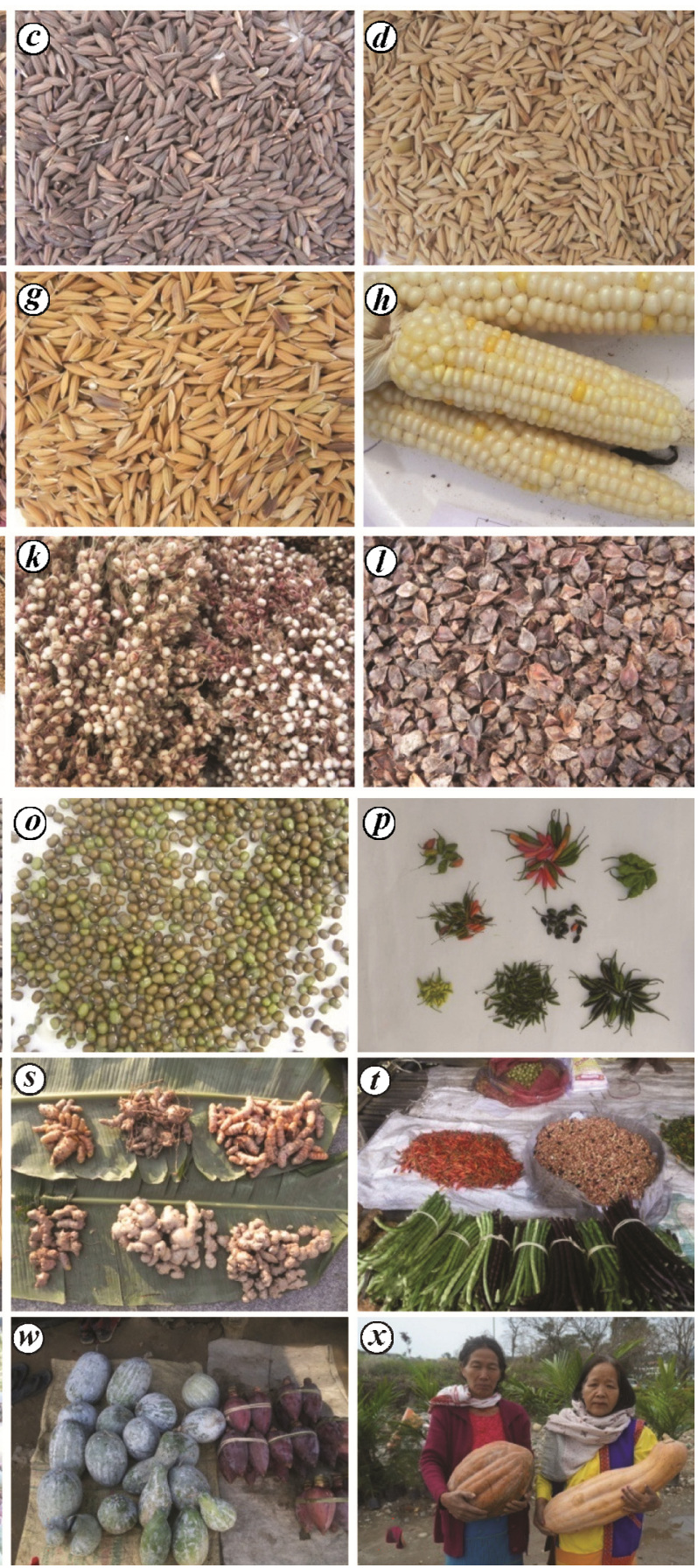

Figure 3. $\boldsymbol{a}-\boldsymbol{g}$, Landrace diversity in rice; $\boldsymbol{f}-\boldsymbol{l}$, Crop diversity in coarse cereals; $\boldsymbol{m}-\boldsymbol{o}$, Crop diversity in pulses; $\boldsymbol{p}, \boldsymbol{q}$, Intra-species diversity in chilli; $\boldsymbol{r}$, Species diversity in tuber crops; $\boldsymbol{s}$, Species diversity in rhizomatous crops; $\boldsymbol{t}-\boldsymbol{x}$, Species diversity in fruits and vegetables.

tendency in the villages towards more modernized lifestyle, people are migrating to small townships for enhanced income and or getting access to more modern goods and services. To some extent, higher education and training in non-farm vocations have increased the opportunity for off-farm employment. However, this scenario has led to less availability of active human resource in the rural areas for farming. More so, most of the rural youth lack knowledge about 'jhumming' cultivation. Therefore, it is expected that the practice of SC would decline substantially in the future. Declining biodiversity with species extinction at the average rate of about two species per day is considered quite startling. Therefore, species inventory and prioritizing species for conservation are 


\section{RESEARCH COMMUNICATIONS}

crucial, especially in this alarming scenario. Such a proactive approach can help sustain a harmonized human-ecosystem balanced planet.

With growing importance and requirement for exploring new cultivars to meet the emerging challenges of climate change and burgeoning human population pressure, the diversified traditional crop species cultivated in SCS may potentially contribute to evolving sustainable crop rotations in agriculture. However, if they represent 'orphan crops' from a plant-breeding perspective, they often lag behind the major crops in terms of having less potential for profitability due to variation in quality and/or less productivity or low consumer preferences, and are consequently less preferred by farmers for cultivation. As a result, such traditional crop species tend to disappear from agricultural production. In this context, the SC landscape is considered a reservoir of alternative genetic resources which can provide more opportunities for the wild relatives of cultivated species having genetic potential for identifying new genes and allelic variability, as well as several other exploitable economic and environmental benefits that can be harnessed with their conservation and cultivation. Such an approach would facilitate their use - both directly and as a part of the breeding programme for related cultivated species, filling the gaps of genetic variability in the primary gene pool.

Declaration: All the authors declare that they have no conflict of interest.

1. FAO, Second global plan of action for plant genetic resources for food and agriculture, Commission on Genetic Resources for Food and Agriculture, Food and Agricultural Organization, Rome, Italy, 2011.

2. United Nations, World population prospects: the 2017 revision, 2018; https://www.un.org/development/desa/en/news/population/ world-population-prospects-2017.html

3. Litrico, I. and Violle, C., Diversity in plant breeding: a new conceptual framework. Trends Plant Sci., 2015, 20, 604-613.

4. Engels, J., Diulgheroff, S. and Alvarez, J. S., Management of Crop Diversity: Key Practices for DRR Implementers, 2014.

5. Pant, R. M., Tiwari, B. K. and Choudhury, D., Report of Working Group III Shifting Cultivation: towards a transformational approach, NITI Aayog, New Delhi, 2018.

6. Kerkhoff, E. and Sharma, E., Debating shifting cultivation in the Eastern Himalayas: Farmers' innovations as lessons for policy. International Centre for Integrated Mountain Development, Kathmandu, Nepal, 2006.

7. Vavilov, N. I., Phytogeographic basis of plant breeding. The origin, variation, immunity and breeding of cultivated plants. Chron. Bot., 1951, 13, 1-366.

8. Darlong, V. T., To jhum or not to jhum: policy perspectives on shifting cultivation. Missing Link (TML), Society for Environment and Communication, New Delhi, 2004.

9. Basnet, D., Kandel, P., Chettri, N., Yang, Y., Lodhi, M. S., Htun, N. Z. and Sharma, E., Biodiversity research trends and gaps from the confluence of three global biodiversity hotspots in the fareastern Himalaya. Int. J. Ecol., 2019, 2019, 1-14; https://doi.org/

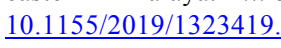

10. Nkoa, R., Owen, M. D. K. and Swanton, C. J., Weed abundance, distribution, diversity, and community analyses. Weed Sci., 2015, 63, 64-90; doi:10.1614/WS-D-13-00075.1

11. Simpson, E. H., Measurement of diversity. Nature, 1949, 163, 688.

12. Yeom, D. J. and Kim, J. H., Comparative evaluation of species diversity indices in the natural deciduous forest of Mt. Jeombong. For. Sci. Technol., 2011, 7, 68-74.

13. Nakro, V., Traditional agricultural practices and sustainable livelihood, a thematic report. Department of Planning and Coordination, Government of Nagaland, 2011.

14. Yumnam, J. Y., Bhuyan, S. I., Khan, M. L. and Tripathi, O. P., Agro-diversity of East Siang, Arunachal Pradesh, Eastern Himalaya. Asian J. Agric. Sci., 2011, 3, 317-326.

15. Teegalapalli, K. and Datta, A., Shifting to settled cultivation: changing practices among the Adis in Central Arunachal Pradesh, North-East India. Ambio, 2016, 45, 602-612; https://doi.org/ 10.1007/s13280-016-0765-x.

16. Alam, M. K. and Mohiuddin, M., Shifting cultivation (jhum) agrobiodiversity at stake: Bangladesh situation. Acta Hortic., 2009, 806, 709-716; https://doi.org/10.17660/ActaHortic.2009. $\underline{806.88}$.

17. DRD, State-wise rice productivity analysis, State: Arunachal Pradesh. Directorate of Rice Development, Department of Agriculture and Co-operation, Patna, 2015; http://drdpat.bih.nic.in

18. Fukuoka, S., Suu, T., Ebana, K., Trinh, L., Nagamine, T. and Okuno, K., Diversity in phenotypic profiles in landrace populations of Vietnamese rice: a case study of agronomic characters for conserving crop genetic diversity on farm. Genet. Res. Crop Evol., 2006, 53, 753-761.

19. Rana, R. B., Garforth, C., Sthapit, B. and Jarvis, D., Influence of socio-economic and cultural factors in rice varietal diversity management on-farm in Nepal. Agric. Human Values, 2007, 24, $461-472$.

20. Lalengzama, C., Agrarian structure and transformation in Mizoram, North East India. J. Hum. Soc. Sci., 2019, 24, 6-23.

21. Tirkey, A., Sarawgi, A. K. and Subbarao, L. V., Studies on genetic diversity in various qualitative and quantitative characters in rice germplasm. Indian J. Plant Genet. Resour., 2013, 26(2), 132137.

22. Dikshit, K. R. and Dikshit, J. K., North-East India: Land, People and Economy, Springer, Dordrecht, 2014.

23. Delang, C. O., Weiyi, X., Brooke, B. and Chun, K. P., The effect of fallow period length on the abundance and diversity of usable plant assemblages in shifting cultivation system (swidden agriculture) in northern Laos. Pol. J. Ecol., 2016, 64, 350-356.

ACKNOWLEDGEMENTS. This study is a part of the Indian Council of Agricultural Research (ICAR) funded research project 'Mapping of socio-economic and livelihood profile of Jhumias in North East India'. The first author acknowledges financial support from the Division of Agricultural Extension, ICAR, New Delhi.

Received 30 June 2019; accepted 9 July 2019

doi: $10.18520 / \mathrm{cs} / \mathrm{v} 117 / \mathrm{i} 8 / 1357-1363$ 